\title{
Vad ska vi med föreläsningar till?
}

\author{
Andreas Håkansson* \\ Mat- och måltidsvetenskap, Högskolan Kristianstad, Kristianstad, Sverige.
}

\begin{abstract}
Föreläsningen är en märklig undervisningsform. Samtidigt som den är den vanligast förekommande metoden, är den också den mest föraktade. Det finns gott om högskolepedagogisk litteratur som förklarar varför föreläsningen är olämplig för att stimulera lärande. Ändå fortsätter vi föreläsa. Det kan tyckas motsägelsefullt.

Denna reflektion vänder på frågan och letar efter föreläsningens fördelar. Utifrån tre öppet tillgängliga föreläsningsserier föreslås tre fördelar med föreläsningen som undervisningsform, fördelar som ofta hamnat i skymundan. De föreslagna fördelarna är: föreläsningar kan genom goda nytolkningar och omformuleringar underlätta inlärningen, den kan ge grund och struktur till nya ämnesområden, och den kan introducera studenter till vad som avses med reflektion på en akademisk nivå.

Slutsatsen är inte att alla föreläsningar nödvändigtvis alltid är motiverade, utan att vi med rätt kunskap och inställning kan föreläsa bättre. Uppenbarligen är det mycket lätt att föreläsa på ett sådant sätt att lärande inte främjas. Men det innebär inte att undervisningsmetoden som sådan är alltigenom oanvändbar. I ljuset av reflektionens tre exempel diskuteras också vad vi kan göra för att föreläsa bättre och vilka implikationer detta har för lärare involverade i högre utbildning.
\end{abstract}

\section{INLEDNING}

Vad ska vi med föreläsningar till? Den frågan ställde sig Donald A. Bligh i en uppmärksammad bok, vars första upplaga utkom I97I (Bligh, 2000). Så här 46 år senare ställer sig många av oss samma fråga. Föreläsningen är en av de mest populära undervisningsformerna på svenska högskolor. Samtidigt finns det en djup skepticism mot föreläsningen i den högskolepedagogiska litteraturen (Elmgren och Henriksson, 2016; Laurillard, 2002; Ramsden, 2003). Det är denna skepticism som föranledde Blighs fråga.

Föreläsningen är lika gammal som universitetsväsendet. Vad vi menar med begreppet föreläsning har visserligen förändrats över tid. Ursprungligen syftade begreppet på en ren uppläsning av texter som studenterna inte hade tillgång till. På Blighs tid hade föreläsningen dock sedan länge utvecklats till ungefär vad den är idag: ett samlingsnamn för undervisningsaktiviteter där en lärare huvudsakligen är den som är aktiv - pratar och demonstrerar - medan studenterna huvudsakligen lyssnar och antecknar vad läraren föredrar.

Blighs klassiska bok är ovanligt kvantitativ i sitt upplägg jämfört med många andra böcker om högskolepedagogik. Bokens första kapitel bygger på en metastudie av effektundersökningar som jämför hur bra föreläsningen står sig relativt andra undervisningsmetoder. Slutsatsen är att föreläsningar fungerar lika bra som andra metoder för att främja studenternas

\footnotetext{
* Författarkontakt: Andreas Håkansson, andreas.hakansson@hkr.se

Artiklar och reflektioner är kollegialt granskade. Övriga bidragstyper granskas av redaktionen. Se www.hogreutbildning.se ISSN 2000-7558

(C)2017 Andreas Håkansson. This is an Open Access article distributed under the terms of the Creative Commons Attribution-NonCommercial 4.0 International License (https://creativecommons.org/licenses/by-nc/4.0/), allowing third parties to share their work (copy, distribute, transmit) and to adapt it, under the condition that the authors are given credit, that the work is not used for commercial purposes, and that in the event of reuse or distribution, the terms of this license are made clear.

Citation: Andreas Håkansson (2017) «Vad ska vi med föreläsningar till?», Högre utbildning 7, 40-50. http:/ldx.doi.org/10.23865/hu.v7.970
} 
informationsinhämtning. Däremot fungerar de sämre för att inspirera studenter, påverka deras värderingar eller förmå dem att se en fråga ur flera perspektiv (Bligh, 2000).

Högskolepedagogiken hjälper oss att förstå vad som är problemet med föreläsningen; många högskolepedagogiska läroböcker och grundtexter tar upp dess tillkortakommande. Exempelvis presenterar föreläsningen information för snabbt för att studenterna ska hinna bearbeta den (Elmgren och Henriksson, 2016; Laurillard, 2002). Den sätter dessutom mer fokus på vad läraren gör och mindre på vad studenten gör, trots att vi vet att lärande förutsätter att studenten aktivt arbetar med studiematerialet (Ramsden, 2003). Ibland talar man lite föraktfullt om detta som att föreläsaren blir a sage on a stage - mer fokuserad på hur han eller hon själv förkunnar, än på hur studenterna lär.

Föreläsningen är helt enkelt en passiv undervisningsform enligt litteraturen. Den ställer stora krav på att studenten själv hittar fram till hur han eller hon aktiverar sig, vilket enligt många högskolepedagogiska företrädare lägger ett orimligt stort ansvar på studenten själv. Resultatet blir att föreläsningen med Laurillards ord blir "hopplöst ineffektiv" (Laurillard, 2002, s. 94). Biggs använder till och med den traditionella föreläsningen som typexemplet för den föråldrade och passiva undervisning som misslyckas med att främja den djupinlärning som vi som lärare har till uppgift att främja (Biggs, 2003, s. 3ff).

Men Blighs dom över föreläsningen är inte enbart negativ. Föreläsningen fungerar trots allt lika bra som andra metoder för informationsinhämtning. Med tanke på att information är första steget mot förståelse, och att föreläsningen dessutom är mycket kostnadseffektiv, skulle vi kunna tolka Bligh som att föreläsningen trots allt har en plats i högre utbildning.

Men kanske är en sådan läsning av Bligh alltför optimistisk när den appliceras på den svenska högskolan. Ett vanligt sätt att motivera det ökade behovet av högskolepedagogik - se exempelvis Biggs (2003), Elmgren och Henriksson (2016) och Ramsden (2003) - är att utgå från hur högskolans expansion föranleder en demografisk förändring av studentsammansättningen. När en större andel av befolkningen går vidare till högre utbildning blir studentgruppen mer heterogen. Förkunskaperna blir sämre och färre av studenterna kommer från studievana hem, resoneras det vidare. Dessa studenter antas inte hemifrån på samma sätt ha nycklarna till hur man som student ska förhålla sig till universitetsutbildning. Därför förutsätts dessa studenter behöva mer stöd för att hitta vägen till djupinlärning - jämför exempelvis Biggs (2003, s. 2) - vilket i sin tur kräver att vi lärare aktivt förändrar vår undervisning så att den blir bättre på att främja dessa angreppssätt.

Utifrån det resonemanget är det rimligt att anta att Blighs slutsatser (som till stor del baserar sig på studier från 50- och 60-talen) överskattar föreläsningens effektivitet. Kanske är den idag inte ens effektiv nog för informationsinhämtning? Med tanke på att även studier utförda på elitutbildningar tycks visa att föreläsningen är relativt ineffektiv (Mazur, 1996), hur illa är det då inte ställt med föreläsningen på de mindre svenska högskolor som i mycket högre omfattning än utbildningarna i allmänhet står för den socioekonomiska breddningen (Broady et al., 2004; Håkansson, 20I6; Svensson, 2006)? Utifrån den högskolepedagogiska diskussionen tycks det märkligt att föreläsningar alls förekommer på svenska lärosäten, och rent förbluffande att de fortsätter att vara den dominerande undervisningsformen.

En annan möjlighet är att det saknas något väsentligt i hur vi beskriver och diskuterar föreläsningen som undervisningsform. Lärande är mycket mer än att bara aktivt bearbeta ett material. Jarvis (2010) beskriver exempelvis lärande som en process av personlig förändring. Den börjar med att studenten upptäcker att det finns ett glapp mellan sin egen världsbild och en ny 
erfarenhet - detta kallar Jarvis för en disjuncture. Lärandeprocessen är sedan den förändring som sker när studenten med hjälp av ny information först reflekterar kring och sedan applicerar nya kunskaper. Ur det perspektivet skulle även en passiv föreläsning kunna ha ett värde, om den exempelvis får studenter att upptäcka dessa disjuncture-glapp eller ger honom eller henne verktyg för att i reflektera systematiskt på nya erfarenheter.

Kanske finns det därför trots allt goda skäl att fortsätta föreläsa, trots de nackdelar den högskolepedagogiska forskningen visat på. I denna reflexion ska vi vända på frågan. Istället för att fokusera på föreläsningens problem används tre fritt tillgängliga och mycket uppskattade föreläsningsserier som grund för en reflektion över föreläsningens fördelar. Urvalet av exempel är varken representativt eller systematiskt, utan ett försök att hitta enstaka fall där många studenter upplever att föreläsningarna hjälper dem i deras lärandeprocess. För att underlätta för läsaren har endast fritt tillgängliga inspelade föreläsningar valts som exempel.

I förlängningen är syftet med denna reflektion att med hjälp av goda exempel skapa en mer nyanserad bild av föreläsningen och hitta vägar mot hur vi kan använda föreläsningar på ett sätt som främjar lärande.

\section{EXEMPEL: I. SUSSKIND, FYSIKEN OCH NYA PERSPEKTIV}

Leonard Susskind, professor i teoretisk fysik på Stanforduniversitetet i Kalifornien, har företagit sig ett ytterst ambitiöst projekt. Under samlingsnamnet The theoretical minimum har han satt ihop en serie kurser (I6 stycken än så länge) riktade till den intresserade allmänheten. Varje kurs består av en serie filmade salsföreläsningar (8-IO x 2 timmar), som gjorts fritt tillgängliga på Internet (The Theoretical Minimum, 20I7). Det som gör föreläsningarna nyskapande är inte så mycket att de behandlar komplicerade begrepp från den teoretiska fysiken som att de inte är lika nedbantade som den typen av introduktionskurser brukar vara. Susskind försöker ge studenten inblick i vad han beskriver som den "riktiga" teoretiska fysiken, som den behandlas av en professionell teoretisk fysiker. Kurserna accelererar därför snabbt från fysikens grunder till abstrakta begrepp som hamiltonianer och operatoralgebra.

Föreläsningarna består mestadels av klassisk envägskommunikation med en kort paus i mitten. Susskinds enda hjälpmedel är den vita tavlan. Studenterna ställer enstaka frågor under tiden, och ibland får de svar av Susskind - om det inte stör hans planering. Det finns inget annat än hans monolog som tvingar studenterna att aktivt arbeta med materialet. Tempot är ofta högt.

Kombinationen av ett avancerat innehåll och den mycket passiva undervisningsmetoden gör det lätt att kritisera Susskinds föreläsningar. Men samtidigt är de väldigt populära. Den första föreläsningen i klassisk mekanik har nästan en halv miljon visningar på Youtube. Därefter avtar intresset, men knappt 50 ooo har enligt visningsstatistiken sett sig igenom alla 20 timmarna av den första kursen.

Susskinds kurser är populära trots att studenterna varken har tid att reflektera eller aktivt arbeta med materialet under själva föreläsningarna. Allt det måste ske på egen hand. Popularitet behöver visserligen inte implicera lärandekvalitet. Men att så många tar sig tid att se dem tyder på att de upplever dem som givande. Att döma av kommentarerna är det hur materialet presenteras som gör föreläsningarna värdefulla. En student skriver exempelvis

"He shows what is important, the essence of the subject. In that way I was able to grasp the fundamental nature of classical mechanics. And this is the biggest challenge of any learning, to 
see the nature of things through the deep fog of technical details, abstractions and formulas." (Youtube, 2017)

Susskinds föreläsningar har enligt studenten ovan en förmåga att ge ett nyskapande och begripligt perspektiv på ett ämne som många upplever som mycket svårt.

Susskindföreläsningarnas succé vilar på deras förmåga att presentera samma innehåll som finns att läsa om i läroböcker, men formulerat och omtolkat på ett sätt som många av studenterna i kommentatorfältet upplever som lättare att förstå. Ingen som ser deras upplägg kan missta sig på att Susskind tänkt länge och hårt på hur materialet ska presenteras. Och det är inte bara en fråga om i vilken ordning innehållet presenteras. Han har en förmåga att utifrån sin breda och djupa kunskap syntetisera fram en ny bild av hur fysiken hänger ihop.

Att ett sådant sätt att presentera materialet underlättar inlärning är inte oväntat utifrån den högskolepedagogiska litteraturen. Att ha förmåga att strukturera kunskapsmassan och sätta den i ett sammanhang lyfts ofta fram som ett kvalitetskriterium för lärare (Chickering och Gamson, 1987; Ramsden, 2003). Utifrån Jarvis modell för lärande skulle vi kunna tolka det som att Susskinds föreläsningar har en förmåga att genom en sådan struktur ge studenterna verktyg tankemässiga eller matematiska - för att sedan på egen hand påbörja det reflekterande och applicerande som leder fram till lärandet.

Susskinds exempel visar att en föreläsning som presenterar en genomtänkt och nyskapande bild av ett kunskapsområde kan främja lärande. Här hittar vi en potential i föreläsningen som undervisningsform som riskerar att glömmas bort när vi fokuserar på undervisningsformens nackdelar.

\section{EXEMPEL 2. GENDLER, MÄNNISKAN OCH TVÄRVETENSKAPLIG FUSION}

Tamar Gendler, professor i filosofi och kognitionsvetenskap på Yaleuniversitetet i Connecticut, har skapat kursen Philosophy and the Science of Human Nature som finns fritt tillgänglig via plattformen Open Yale Courses (Yale, 20I7a). Kursen är något svårplacerad i den traditionella akademiska traditionen. Den kan inte enkelt klassificeras som varken psykologi, religion, litteraturvetenskap eller psykologi, utan innehåller element från dem alla.

Kursens stomme är Gendlers föreläsningsserie ( 26 x 50 minuter). Men de campusstudenter som läser kursen för akademiska poäng behöver också lämna in veckovisa skriftliga uppgifter, två längre uppsatser och genomgå skriftlig examination (Yale, 20I7a).

Föreläsningarna är traditionellt uppbyggda med ytterst begränsad studentaktivitet, trots att de är relativt långa. Gendler föreläser stillsamt bakom sin pulpet och använder en PowerPointpresentation för att uppmärksamma åhörarna på viktiga delar. Gendler har, liksom Susskind, inte lagt in några pedagogiskt motiverade avbrott eller reflektionsövningar för att aktivera studenterna. Men innehållet är upplagt med stor eftertanke och med ambitionen att engagera studenterna och stimulera deras akademiska utveckling. Första tredjedelen av kursen bygger exempelvis på ett tankeexperiment med den uttalade avsikten att ge studenterna ett intresseväckande problem att ta ställning till - skulle du verkligen agera moraliskt om ingen kunde ser vad du gör? Gendler använder sedan allt från litteratur, antika filosofer och modern kognitionsvetenskaplig forskning för att bearbeta frågan.

Frågor som denna har behandlats i akademiska kurser förut. Det som gör Gendlers föreläsningar nyskapande är sättet på vilken de smälter samman olika vetenskapliga discipliner för att 
belysa den mänskliga naturen. Föreläsningarna fastnar inte i ett ämnesområde utan rör sig ledigt däremellan. Ambitionen är att studenterna efter kursen ska kunna göra samma sak.

Gendlers exempel visar på en fördel med att använda föreläsningar. Utifrån Jarvis (2010) teori kan vi se hur hennes användning av antika myter för att illustrera komplexiteten i den moraliska frågan blir till det Jarvis kallar en disjuncture - det visar på att verkligheten är mer komplicerad än vad vi först trott, vilket enligt Jarvis är vad som motiverar oss att börja reflektera.

Denna reflektion kräver att studenten kan bilda sig en struktur av kunskapsstoffet. För att strukturera sitt arbete behöver studenten ofta stöd av en lärare, och dessutom någonstans att inhämta grundfakta ifrån. I Susskinds fall (klassisk mekanik) skulle struktur och grundfakta kunna inhämtas från en lärobok. Men för Gendlers kurs, som är nyskapande och tvärvetenskaplig, finns det ingen lärobok att tillgå. Mer studentaktiverande undervisningsformer, som exempelvis problembaserat lärande eller peer instructions (Mazur, 1996), förutsätter att det finns en annan källa där studenterna kan inhämta struktur och erforderliga grundfakta.

Bristen på passande kurslitteratur är inte unikt för Gendlers kurs. Speciellt vanligt blir det när vi betraktar tvärvetenskapliga och tematiska kurser, eller kurser som inte följer traditionella akademiska ämnesområden. Med insikten om att vi behöver mer tvärvetenskaplighet i akademin kommer detta att bli ett allt större problem. Kanske har vi därför anledning att i framtiden använda fler föreläsningar snarare än färre, i alla fall om vi kan presentera innehållet lika genomtänkt och lärandefrämjande som i Gendlers föreläsningar.

\section{EXEMPEL 3. KaGAN, DÖDEN OCH DEN DJUPA TANKEN}

Shelly Kagan är professor i filosofi, också han på Yale. Han har skapat Death, en kurs i filosofi på introduktionsnivå. Kursen är tematiskt uppbyggd och introducerar studenterna i filosofens sätt att resonera om döden som fenomen. I centrum av kursen står tre frågeställningar: Har människan en själ? Är det dåligt att dö? Är suicid försvarbart? Detta är ett otraditionellt sätt att organisera en introduktionskurs i filosofi. Istället för att sakligt redogöra för filosofins utveckling eller "skolor" ställer Kagan sina studenter inför tre frågor som det är mycket svårt att värja sig mot. Det är också här fråga om ett från lärarens sida medvetet grepp för att engagera och genom kursens upplägg stimulera studenternas intresse. Utifrån Jarvis (2010) modell kan vi se dessa frågor som försök att åstadkomma disjuncture. Studenterna ska tvingas inse att de intuitiva svar på dessa frågor de bär på antingen är ohållbara eller behöver beläggas med bättre argument.

Också denna kurs finns tillgänglig på Open Yale Courses (Yale, 20I7b), och dess ryggrad är en föreläsningsserie ( 26 x 50 minuter) levererad av Kagan själv. Hans föreläsningsstil är betydligt ledigare än Susskinds eller Gendlers. Kagan sitter helst med benen i kors på katedern och resonerar eftertänksamt inför sina studenter. Ibland stiger han upp för att illustrera någonting på griffeltavlan. Föreläsningarna inbjuder inte till någon större aktivitet. Takten är visserligen sällig och hans resonemang eftertänksamt, men det är Kagans reflektion och eftertanke som står i fokus, inte studentens. Studenterna får ställa frågor, men Kagan gör inte mycket för att stimulera detta; totalt blir det bara en handfull under kursens 22 föreläsningstimmar.

Om Kagan velat byta ut sina föreläsningar hade han ställts inför samma problem som Gendler. Upplägget i hans kurs är unikt. Om han inte ska behöva göra avkall på sin pedagogiska idé kan han inte förlita sig på en lärobok. Men utöver detta illustrerar Kagan en annan potentiell fördel med föreläsningen som undervisningsform. Det Kagan ägnar sina föreläsningar åt är nämligen inte att sakligt och kronologiskt presentera vad olika tänkare har sagt om döden. Istället 
argumenterar han utförligt för sitt svar på kursens tre frågeställningar. Kagans syfte är inte att övertala studenterna att de i slutändan måste tycka som han (Kagan, 20I2, s. 4; Yale, 20I7b), utan att genom föreläsningarna visa hur en filosofisk argumentation fungerar. Denna intention är han tydlig med att presentera redan under kursintroduktionen. Det studenterna får se är en uppvisning i hur en mästare behandlar det ämne de är där för att lära sig: hur läraren presenterar olika argument, kritiserar svaga argument från litteraturen, lyfter fram styrkor i andra och till sist syntetiserar ett sammanfattande svar. Kagan ägnar föreläsningarna åt en djup och ingående reflektion.

Burgan (2006) har redan tidigare lyft upp just detta som en av föreläsningens ofta förbisedda fördelar. Burgan menar att en grundnivåstudent knappast kan förväntas ha verktygen för att själv börja reflektera på detta vis om vi som lärare aldrig visar hur det går till. Det Kagan gör beskriver Burgan som ett uttryck för en av föreläsningens styrkor, den visar "knowledgable adults groupling with first principles in order to open up their students' understanding" (Burgan, 2006, s. 33). Tolkat utifrån Jarvis (2010) modell för lärande kan vi se det som att det Burgan efterfrågar och som Kagan gör är att visa hur den reflektion studenterna vid ett senare tillfälle själva måste ge sig i kast med kan byggas upp.

Vi kan ha olika åsikter om huruvida det behövs 22 timmar av detta, men att helt ersätta dessa moment med ett seminarium där studenterna utan denna typ av goda exempel ombeds "reflektera" är inte mindre problematiskt, framförallt för de studenter som inte sedan tidigare känner sig hemma i en akademisk miljö.

\section{INVÄNDNING I. BOKEN SOM ALTERNATIV}

Ur dessa tre exempel på framgångsrika föreläsningsserier ser vi tre potentiella fördelar med föreläsningar som ofta förbises när vi diskuterar undervisning på högskolan: dels kan föreläsningar genom nytolkningar och omstrukturering av materialet underlätta inlärningen, dels kan de ge grund och struktur till nya ämnesområden, och dels kan det introducera studenter till hur det går till att reflektera på en akademisk nivå.

Men mot alla dessa exempel går det att resa en invändning. De potentiella fördelarna med Susskinds, Gendlers och Kagans undervisning tycks egentligen inte vila så mycket på föreläsningarna i sig som på att de som kompetenta lärare har bearbetat materialet och genom ett student- och lärandecentrerat perspektiv bygger en medveten struktur i kursen. Skulle inte allt det Susskind, Gendler och Kagan gör i föreläsningsform lika gärna kunna sammanfattas skriftligt? Då hade de kunnat använda den värdefulla undervisningstiden till mer studentaktiverande former utan att förlora sina styrkor.

Men detta alternativ är knappast genomförbart. Gendlers transkriberade föreläsningar omfattar ungefär I30 ooo ord (Yale, 20I7a), motsvarande en genomsnittlig lärobok. Att omarbeta ett föreläsningsmanuskript av den omfattningen till en bok är en enormt tidskrävande uppgift, även för en akademiker som har samma skrivvana som Susskinds, Gendlers och Kagans publikationslistor indikerar att de har. I praktiken är det knappast ett alternativ att skriva en bok för varje kurs istället för att ge föreläsningar, framförallt för högskolelärare med omfattande undervisningsuppdrag som undervisar många olika kurser.

Man kan mycket väl tänka sig att den här typen av genomtänkta föreläsningsserier utvecklas till läroböcker med tiden, efter den återkoppling mötet med studenterna ger. För varje år putsar föreläsaren lite på sitt manuskript, läser lite till och justerar de delar som inte gick hem hos studenterna. I själva verket är detta fallet för flertalet av dessa exempel. Susskind har utvecklat 
tre av sina I6 kurser till böcker (Susskind och Hrabovsky, 20I4; Susskind och Friedman, 2015, 20I7) och Kagan skrev slutligen en bok utifrån sina föreläsningar om döden (Kagan, 20I2). Men det finns en betydelsefull riktning här, böckerna har växt fram ur deras föreläsningserfarenheter.

Utan föreläsningarna är det tveksamt om böckerna kommit till. Genom föreläsningarna har de dessutom fått möjlighet att testa sina omtolkningar, fusioner och reflektioner på hundratals studenter. De har kunnat lägga till och dra ifrån, utveckla och förenkla. Med tiden har det lett fram till böcker. Men det innebär inte att böcker kan ersätta föreläsningen, snarare tycks föreläsningarna vara förutsättningar för att denna typ av nydanande läroböcker alls ska komma till.

\section{INVÄNDNING 2. LÄRANDE ELLER UNDERHÅLLNING}

En annan invändning mot att se Susskinds, Gendlers och Kagans föreläsningar som goda exempel är i vilken mån deras popularitet egentligen handlar om lärande. Kanske är det inte för att lära sig fysik som hundratusentals tittar på Susskind, utan för att det helt enkelt är underhållande att se denna smått excentriska professor roa sin publik med yviga gester och mystiska formler.

Eric Mazur, själv fysikprofessor på Harvarduniversitetet och en namnkunnig förespråkare för högskolepedagogiskt tänkande, lyfts ofta fram för att göra just denna invändning mot traditionella föreläsningar som får goda studentomdömen. Mazur berättar hur både han själv och studenterna alltid uppfattat honom som en mycket god föreläsare. Men när han en gång fick för sig att ändra examinationsmetoden till en mer förståelseinriktad form upptäckte han att studenterna trots det hade betydande kunskapsluckor (Mazur, 1996). Hans föreläsningar var uppenbarligen underhållande och genomtänkta, men ändå lärde sig studenterna inte.

Mazurs framgångar med att byta bort föreläsningar mot studentdiskussioner och studenter som lär varandra (peer instruction) nämns ibland som ett bevis på att föreläsningen i bästa fall är underhållande, men alltid ineffektiv. Samma sak skulle kunna gälla för Susskind, Gendler och Kagan. Men detta är en vantolkning av Mazurs resultat. Det Mazur gör är inte att ta bort alla föreläsningar, utan att byta ut en del av dem mot mer aktiva moment - ungefär hälften av undervisningsmomenten består fortfarande av klassiska föreläsningar (Crouch och Mazur, 20oI). Problemet tycks inte ha varit att Mazurs föreläsningar varit mer underhållning än lärande utan att de behövde blandas upp med andra mer aktiva inlärningsmetoder. Föreläsningen kan uppenbarligen främja lärande, i alla fall om den kombineras med andra metoder.

\section{INVÄNDNING 3. LÄRARE MEN INGET LÄRANDE}

En tredje invändning mot att se Susskinds, Gendlers och Kagans föreläsningar som goda exempel kan vi hitta i Blighs (2000) 46 år gamla text: Om föreläsningen inte har förmågan att främja nytänkande eller främja djup i tanken, vilken nytta har det då gjort att Susskind har förmågan att ge nyskapande perspektiv på fysiken, att Gendler kan smälta samman många ämnesområden till en genomtänkt tvärvetenskaplig kurs eller att Kagan kan resonera djupt inför publik? I så fall är deras agerande endast betydelsefullt för dem själva, inte för studenterna. Vi är tillbaka i den gamla sage-on-a-stage-invändningen, att föreläsningen tycks fokusera alltför mycket på vad läraren gör och alltför lite på vad studenten gör eller lär (jfr Ramsden, 2003, s. I48).

Men denna invändning håller inte heller, åtminstone inte generellt. Det Bligh visar är att föreläsningsformen i flertalet fall inte främjar djupare tankar. Men det kan knappast vara en överraskning för någon som genomlevt en akademisk utbildning. Det är väldigt lätt att ge 
en dålig föreläsning. Vem har inte upplevt lärare som entonigt betar av en PowerPoint som antingen är en direkt kopia av vad som står i läroboken eller i detalj redogör för någon obskyr aspekt av sin egen forskning, utan att visa hur dessa detaljer hänger samman eller förhåller sig till ämnesområdet i stort. Att flertalet föreläsningar inte främjar djup tanke behöver inte betyda att föreläsning är en dålig undervisningsform. Det kan lika gärna betyda att vi behöver bli bättre på att föreläsa.

Om vi som Bligh begränsar oss till effektundersökningar finns det få nutida motsvarigheter. John Hatties projekt för att undersöka vad som rent statistiskt har effekt för att öka lärandet i grundskolan är troligen det som kommer närmast (Fisher et al., 20I6). Hans forskning gäller i första hand grundskolan, men baserat på sina generella insikter om lärande har han också extrapolerat till högskolan (Hattie, 20I5). Hattie har inte samma odelat negativa inställning till föreläsningen som många högskolepedagogiska auktoriteter (jämför exempelvis med Laurillard, 2002, s. $92 \mathrm{ff}$ och Ramsden, 2003, s. I48). Hattie konstaterar att de flesta av de undervisningspraktiker som genom effektstudier framkommer som lärandebefrämjande kan uppnås genom föreläsningsformen (Hattie, 20I5, s. 84). Dessutom, fortsätter han, har föreläsningen en stor fördel i att den är kostnadseffektiv. Eftersom Hattie inte hittar några negativa effekter av stora undervisningsgrupper (Fisher et al., 20I6; Hattie, 20I5), ger föreläsningarna förutsättning för att varje student ska få mer undervisningstid jämfört med om läraren istället använt andra metoder. Hattie konstaterar visserligen att föreläsningen inte ensam kommer att räcka för att främja god inlärning. Men kurser helt utan andra undervisningsformer än föreläsningar är ytterst ovanliga. Om vi exkluderar Susskind, vars föreläsningsserier inte är del av poänggivande kurser, inkluderar de övriga två exemplen trots sina många och långa föreläsningar en rad andra aktiviteter, exempelvis lärarledda diskussioner, uppsatser, skriftliga prov och inlämningsuppgifter. Föreläsningarna är många och omfattande men att lyssna på dem är bara en liten del av det arbete studenterna måste lägga på kurserna. Varken föreläsningen eller någon annan undervisningsform har möjlighet att själv erbjuda allt som behövs för ett gott lärande. Men det innebär inte att vi kan utesluta att de ändå har en plats i mixen.

\section{KONKLUSIONER OM DEN GODA FÖRELÄSNINGEN}

Utifrån Susskins, Gendlers och Kagans exempel tycks det finnas anledningar att fortsätta föreläsa, i alla fall om det sker på rätt sätt. Men vad är det i så fall som gör just dessa föreläsningar goda och vilka lärdomar kan vi andra dra av deras exempel?

Den högskolepedagogiska litteraturen ger ett svar på frågan om vad som karakteriserar den goda föreläsningen. Bligh (2000) beskriver hur föreläsningen bör utformas för att främja tänkande. Framförallt måste vi enligt Bligh (2000) arbeta aktivt med att få studenterna att tänka under föreläsningarna, exempelvis genom att anpassa tempot, ställa frågor eller låta studenterna formulera egna frågor.

Andra högskolepedagogiska forskare ger andra förslag. deWinstanley och Bjork (2002) pekar på vikten av att under föreläsningar tillhandahålla struktur, engagera studenterna och använda strategiskt placerade avbrott för att underlätta studenternas förmåga att bearbeta innehållet $\mathrm{i}$ föreläsningen. Biggs (2003, s. 82) föreslår olika metoder för att göra studenterna mindre passiva under föreläsningarna, och exemplifierar med konceptkartor. Dessa metoder är bevisligen nyttiga. Men Susskind, Gendler och Kagan gör inget av detta. Dessa exempel pekar mot att det finns en annan viktig skillnad mellan bra och dåliga föreläsningar. 
Den starkaste gemensamma faktorn för Susskind, Gendler och Kagan har mindre att göra med föreläsningarnas teknik, eller hur föreläsningsmonologen kan brytas av, och mer med deras innehåll. De undervisar tre helt olika kurser och föreläser på tre olika sätt. Men de använder sin förmåga att syntetisera, sammansmälta, omtolka och kontrastera på en mycket hög nivå. Tydligast framgår det kanske om vi kontrasterar deras sätt mot en betydligt vanligare föreläsningsform där läraren "föreläser boken", det vill säga rubrik för rubrik och kapitel för kapitel redogör vad som står i kurslitteraturen. Det är svårt att se vad det alls skulle finnas för fördelar med en sådan föreläsning. Naturligtvis kan en sådan föreläsning bli bättre genom att avbrytas av bikupor eller reflektionsövningar. Men det är tämligen självklart att en sådan föreläsning blir bättre av att avbrytas med andra lärandefrämjande aktiviteter eftersom den i sig själv inte tillför något som inte redan finns i kurslitteraturen. I så fall är det troligen bättre att gå hela vägen och ersätta hela föreläsningen med diskussioner och egen läsning.

Susskind, Gendler och Kagan gör någonting helt annat. Kanske är det till och med orättvist att tala om det de gör och om att "föreläsa boken" som samma undervisningsmetod. Om kurslitteraturen alls nämns är det i förbigående för att peka på en kontrast eller göra en hänvisning till sådant studenten förväntas läsa om på egen hand. Deras exempel visar att den goda föreläsningen inte endast behöver handla om hur vi gör mikropauser eller lägger in reflektionsmoment, utan också om hur vi bearbetar det material vi föreläser.

Att ett sådant sätt att föreläsa kan bli lärandefrämjande framgår exempelvis om vi återigen tolkar mina exempel genom Jarvis (20I0) modell. Det Susskind, Gendler och Kagan gör är att ta ansvar för att främja lärande, dels genom att presentera innehållet på ett sådant sätt att studenterna inser glappet mellan vad de redan vet och världens komplexitet (disjuncture), och därefter presentera studenterna för de reflektionsverktyg de behöver för att väva in dessa nya erfarenheter och applicera dem, oavsett om detta är i form av matematiska formler (Susskind), en mångfald av vetenskapliga perspektiv (Gendler) eller filosofisk argumentationsteknik (Kagan). Här är det viktigt att påpeka att detta förutsätter att studenterna faktiskt också får tillfälle att själva göra dessa reflektioner, som en del av andra lärarledda inlärningsaktiviteter eller på egen hand. Som lärare har vi inte bara ett ansvar att ge verktyg för reflektion utan också att tydliggöra att det inte räcker för en student att lyssna på andra som reflekterar. På den punkten kunde både Susskind, Gendler och Kagan ha varit mycket tydligare.

\section{IMPLIKATIONER FÖR HÖGSKOLELÄRAREN}

Dessa förslag på vad som skiljer den goda från den dåliga föreläsningen har viktiga implikationer för oss som högskolelärare. Att som Susskind omtolka den teoretiska fysiken, hela vägen från Newton till kvantmekanik och M-teori, kräver betydligt mer än att redogöra för vad en läroboksförfattare skrivit. Att som Gendler föreslå en ny syntes av kognitionsvetenskap, filosofi, litteratur och psykologi kräver både bred kunskap och en mycket hög förmåga till syntes. Och att som Kagan själv använda historiska filosofer för att bygga ett 20 timmar långt filosofiskt försvar för tre kontroversiella ställningstaganden är svårare än att läsa upp PowerPoint-presentationer över filosofins historia.

Den goda föreläsningen tycks inte bara innebära mer och hårdare arbete för oss lärare, utan dessutom kräva exceptionella akademiska förmågor. I så fall ligger kanske problemet inte så mycket på föreläsningen som på de svårigheter vi föreläsare har med att hantera undervisningsformen. 
Susskind, Gendler och Kagan befinner sig i det absoluta toppskiktet inom sina respektive fält, de är professorer på världsledande lärosäten och är internationellt erkända och prisbelönta auktoriteter. Det finns en viss intellektuell likhet mellan att producera nytänkande och omdanande forskning i framkant och att producera den typ av föreläsningar som Susskind, Gendler och Kagan håller - båda kräver förmågan att ta in stora mängder kunskap, kritiskt sammanställa, syntetisera och omformulera. En kunskapsnivå som är betydligt djupare och bredare än kursinnehållet, samt forskningsskicklighet inom ämnesområdet garanterar naturligtvis inte goda föreläsningar, men, kan man fråga sig, är det alls möjligt att innehållsmässigt föreläsa på det sättet som Susskind, Gendler och Kagan gör utan dessa färdigheter?

Att förbättra sina föreläsningar med de metoder högskolepedagogiska läroböcker ofta föreslår (exempelvis konceptkartor, bikupor eller peer instructions-inslag) är relativt lätt, det är en förmåga vi kan lära oss ( Biggs, 2003; Ramsden, 2003). Och därför finns det goda anledningar att fortsätta sprida dessa metoder. Men kanske är detta inte alltid tillräckligt. Den djupa analysförmåga som föreläsarna i mina tre exempel visar prov på är betydligt svårare att tillägna sig. Tyvärr är det därför svårt att från de tre exemplen härleda några konkreta förslag på vad vi rent praktiskt ska göra för att föreläsa bättre, de leder inte fram till någon enkel formel eller metod. Det vi behöver göra är att fortsätta odla vår allmänna akademiska förmåga.

Dessa tre exempel föreslår också att vi kanske misstar oss på vad som är rotorsaken till att vi som högskolelärare behöver ägna mer kraft på högskolepedagogisk utveckling idag jämfört med de lärare som var verksamma för ett par decennier sedan behövde göra. Högskolepedagogiska läroboksförfattare skriver ofta att anledningen till att många studenter idag har svårt att nå upp till de akademiska kraven är att de är sämre förberedda för universitetsstudier, delvis på grund av bristande förkunskaper och delvis på grund av att allt fler kommer från studieovana miljöer där de inte får med sig de akademiska verktygen hemifrån (se exempelvis resonemanget i Biggs, 2003, s. 3ff). Utifrån en sådan beskrivning blir högskolepedagogisk utveckling allt viktigare som en reaktion mot en förändring hos studenterna. Det kan ligga någonting i detta. Men svårigheterna med att föreläsa mästerligt visar att problemet också kan ligga på oss lärare.

Expansionen av högskoleutbildning innebär en expansion av antalet lärare. Enligt Universitetskanslerämbetets statistik fanns det 29000 forskande och undervisande personal på svenska högskolor och universitet 2016 (UKÄ, 20I7). Och alla kan vi inte vara en Leonard Susskind, Tamar Gendler eller Shelly Kagan i våra respektive fält. Kanske är det inte bara studenterna som blivit sämre förberedda för högskolestudier, kanske är det också så att vi som undervisar inte alltid har den förmåga som krävs för att ge riktigt goda föreläsningar. Kanske är problemet inte föreläsningsformen som sådan, utan att det är mycket lättare att misslyckas med att föreläsa än med att leverera många andra former av undervisning. I så fall bör vi kanske snarare satsa på att hjälpas åt att hitta vägar mot bättre föreläsningar än att fördöma undervisningsformen som sådan.

\section{TACK}

Jag vill tacka deltagarna i workshopen Föreläsningen - en diskussionsserie vid Högskolan Kristianstad VT 2017 för givande diskussion och inspiration till denna reflektion. 


\section{FÖRFATTARPRESENTATION}

Andreas Håkansson är biträdande professor i mat- och måltidsvetenskap på Högskolan Kristianstad där han huvudsakligen undervisar blivande gastronomer och grundskolelärare i hem- och konsumentkunskap.

\section{REFERENSER}

Biggs, J. (2003). Teaching for quality learning at university. Maidenhead, UK: Open University.

Bligh, D.A. (2000). What's the use of Lectures? San Francisco, CA: Jossey-Bass.

Broady, D., Börjesson, M. \& Lidegran, I. (2004). Vad väljer studenterna? Utbildningssociologiska reflektioner kring högskolors rekrytering. http://www.skeptron.uu.se/broady/sec/p-broady-borjessonlidegran-041020-SUHF.pdf (hämtad 2017-08-17)

Burgan, M. (2006). In defense of lecturing. Change: The Magazine of Higher Learning 38(6), 30-34.

Chickering, A.W., \& Gamson, Z.F. (1987). Seven Principles for Good Practice in Undergraduate Education. American Association of Higher Education Bulletin, March 1987, 2-6.

Crouch, C. H. \& Mazur, E. (200I). Peer instruction: Ten years of experience and results. American Journal of Physics 69, 970-977.

deWinstanley, P. A. \& Bjork, R. A. (2002). Successful Lecturing: Presenting Information in Ways That Engage Effective Processing. New Directions for Teaching and Learning 89, 19-3I.

Elmgren, M. \& Henriksson, A.-S. (20I6). Universitetspedagogik. Lund: Studentlitteratur.

Fisher, D., Frey, N. \& Hattie, J. (2016). Visible Learning for Literacy. Thousand Oaks, CA: Corwin.

Hattie, J. (2015). The Applicability of Visible Learning to Higher Education. Scholarship of Teaching and Learning in Psychology I(I), 79-9I.

Håkansson, A. (20I6). Den långlivade segregationen mellan lärosäten - ett högskolepedagogiskt perspektiv. Högskolepedagogisk debatt I/20I6, 24-45.

Jarvis, P. (20IO). Adult education and lifelong learning: theory and practice. London, UK: Routledge.

Kagan, S. (20I2). Death. New Haven, CT: Yale University Press.

Laurillard, D. (2002). Rethinking university teaching. London, UK: Routledge Falmer.

Mazur, E. (1996). Peer Instruction: A User's Manual. London, UK: Pearson.

Ramsden, P. (2003). Learning to teach in higher education. London, UK: Routledge Falmer.

Susskind, L. \& Friedman, A. (2015). Quantum Mechanics: The Theoretical Minimum. London, UK: Allen Lane.

Susskind, L. \& Friedman, A. (20I7). Special Relativity and Classical Field Theory: The Theoretical Minimum. London, UK: Allen Lane.

Susskind, L. \& Hrabovsky, G. (20I4). Classical Mechanics. The Theoretical Minimum. London, UK: Penguin.

Svensson, A. (2006). Hur ska rekryteringen till högskolans mest eftersökta utbildningar breddas? Pedagogisk forskning i Sverige, II(2), ss. II6-I33.

The Theoretical Minimum (20I7). The Theoretical Minimum homepage. http://theoreticalminimum. com/home (hämtad 20I7-08-I7)

UKÄ (20I7). Statistikdatabas över högskolan. Universitetskanslerämbetet. http://statistik.uka.se/ (hämtad 2017-08-I7)

Yale (2017a). Phil I8r: Philosophy and the science of human nature. Open Yale Courses. http://oyc.yale. edu/philosophy/phil-18I (hämtad 2017-08-I7)

Yale (20I7b). Phil 176: Death. Open Yale Courses. http://oyc.yale.edu/philosophy/phil-I76 (hämtad 2017-08-17)

Youtube (20I7). Classical mechanics - Lecture Io. Standford University. https://www.youtube.com/ watch?v=bn5lKYHenSQ (hämtad 2017-08-17) 